\title{
EFFECTS OF TEMPERATURE LEVELS AND CONCRETE COVER THICKNESS ON RESIDUAL STRENGTH CHARACTERISTICS OF FIRE EXPOSED REINFORCED CONCRETE BEAMS
}

\author{
F. Kigha ${ }^{1}$, J. A Sadeeq ${ }^{2}$ and O. S. Abejide ${ }^{3, *}$ \\ 1, 2, 3 Department of Civil EngineEring, Ahmadu Bello University, Zaria. Kaduna State. NigERIA. \\ E-mail addresses. ${ }^{1}$ mckighan@gmail.com, ${ }^{2}$ jasadeeq@yahoo.com, ${ }^{3}$ abejideos@yahoo.com
}

\begin{abstract}
Reinforced concrete structures are often subjected to fire of various degrees. After fire if the structure does not collapse during the fire there is need for post-fire assessment of its structural integrity before the fate of the structure can be determined. With the knowledge of the temperature of the fire, thickness of concrete cover, residual strength of concrete and tensile strength of embedded reinforcement after fire exposure, we can predict the residual carrying capacity of the beams after fire. The experimental procedure involves some specimens of reinforcing steel bars ( $\phi 16 \mathrm{~mm}$ ) enclosed in varying concrete covers in concrete beams which were exposed to ISO 834 furnace temperatures for 2hrs. After fire, the steel bars were removed and tested for tensile strength characteristics and the reduction in strength trend compared with the current code predictions for stress strain relationship of hot-rolled reinforcing steels at elevated temperatures. The variation in the residual moment and shear capacities of the reinforced concrete beams with temperature were evaluated. The experimental residual strength index was found to be greater than the theoretical prediction in the code. The variation in cover thickness of concrete to embedded reinforcement in beams was also noticed to be of no significance to the post-fire tensile strength of the steel reinforcement if the fire temperature is below $700^{\circ} \mathrm{C}$.
\end{abstract}

Keywords: Post-fire, flexure, residual strength, concrete cover, tensile strength, iso834 fire.

\section{INTRODUCTION}

Reinforced Concrete is one of the composite materials that have been regarded as the most versatile construction material known to man and used in civil engineering structures and application [1]. It is by far a durable material with a design life of about 60yrs and environmentally friendly. It is used to construct structural members such as columns, beams, foundation as well as road pavement, retaining walls etc. Reinforced concrete beams (precast or cast insitu) are major members in buildings and bridges for safe transfer of loads to the foundation. There are three types of loads that affect structures [2, 3]: primary loads, secondary loads, and special loads. Primary loads are loads which permanently or very often affect the structure. These could be dead loads, live loads, shrinkage-creep loads, etc. Secondary loads are loads which affect the structure less often, such as wind loads, snow loads, seasonal temperature changes, etc. Special loads are loads which seldom affect the structure, for example, earthquake loads, fire loads, critical accident loads, etc. Fire, a special load which has to be considered when structures are designed, is in essence a sudden energy (or heat) discharge on the structure.

The action of loads on beams induces flexure, torsion, shear and thermal stresses on a beam element. Hence a safe beam should be able to provide resistance to these stresses. Beams are designed to resist these loads efficiently and economically using various design methods.

Special load actions during the life of a structure, is probabilistic and depends on the environment [4]. It is generally quite difficult to gather authentic information on structural fires which are complex phenomena. Information may be obtained by theoretical or experimental research work but the most straightforward way is to obtain information on the structural behavior during fires by a careful inspection of the structures which have undergone fires [2]. 
From the fire resistance point of view, reinforced concrete beams pose important stability issues in the event of fire accident in a building structure or a tanker or car fire under a highway bridge. This could result in the reduction of the structural integrity of the system which can be noticed from spalling of concrete, reduction in the yield strength of the tensile reinforcement and the overall carrying capacity of the beam $[5,6,7]$. Design codes consider fire by specifying minimum dimensions for members to withstand fire for specific duration. However, the codes have no recommendation in cases where the structure does not collapse after fire. But when the building structure or elements does not collapse, the extent of damage due to the fire on the inner strength or load carrying capacity of the member is not the same prior to fire exposure. Therefore, an assessment of the actual strength or load carrying capacity of the resulting structure need be established in order to ensure a good decision on economy and structural safety.

\section{WORK DONE ON CONCRETE SUBJECTED TO FIRE}

Experimental evaluation of reinforced concrete beams in fire has suggested that the fire resistance duration was far greater than the theoretical estimated period[8].According to Alonso [9] in post fire assessment of concrete structures, several techniques used to determine the depth of concrete affected by fire do not accurately discriminate between the type of damage; physical or chemical. Ellinwood [10] performed a reliability analysis of reinforced concrete beams in fire in which they incorporated the time temperature-dependent strength degradation of steel as well as the thermal creep. They proposed that the after fire safety of these beams can be developed which will be commensurate with the required reliability and level of uncertainty arising from basic randomness in modeling.

Concrete whether it spalls in fire or not, still has some mechanical strength. But the strength of the concrete is affected by the fire to a certain depth below the surface of the beam $[11,12,13]$. According to Gerritse [14], concrete is one of the most fire resisting materials when it comes to ISO-fires and that if there is a collapse in a fire, it will be because of the buckling of reinforcement at its critical temperature. Abeles and Barhan-Roy [15] pointed out that the residual strength of light weight aggregate concrete decreases linearly from $100 \%$ to $40 \%$ from about $500^{\circ} \mathrm{C}$ to $800^{\circ} \mathrm{C}$ and for normal concrete, the residual strength is about $20 \%$ at $800^{\circ} \mathrm{C}$ while, for normal reinforcement the strength reduction is about $50 \%$ at $500^{\circ} \mathrm{C}$. But this does not tell us whether the reinforcement is in direct contact with fire or embedded in a concrete cover.

Jensen et al [16] conducted tests on cooled light weight aggregate concrete using hydrocarbon fire which has a higher temperature than ISO-fire and concluded that the addition of polypropylene fibre in the mix will increase the residual strength from zero to about 50\%. According to Hammer[17] the load capacity of concrete after fire has reduced even if the visual or physical damage is negligible; and Alonso[9] in the same vein said that, none of the non-destructive test and destructive tests can be able to determine the loss in mechanical strength because of the heterogeneous gradient of damage in the concrete element.Hydrocarbon fire test with passive fire protection has shown that the temperature of the concrete surface could not exceed $400^{\circ} \mathrm{C}$ for a 2 hours fire exposure $[18,19]$.

Concrete structures are often exposed to accidental fires; and during these fires most of the structures do not collapse completely (at the ultimate limit state) and are sometimes rehabilitated. There is therefore the need to check the structural capacity of critical members in the structure, by combining the post fire characteristics of the member materials, before commencing the repairs. This paper can be used as a guideline to assess the structural integrity of fire affected structures as well as recommend the type of repairs that can be done to the structures. The post fire resistance of a beam to loads depend on the temperature attained during the fire by the concrete and embedded steel. In other words the post fire characteristics of the beam depend on the individual structural component materials and size parameters.

\subsection{Residual strength index:}

The Residual Strength Index (RSI) of a beam element can be defined as the ratio of the strength after the fire to the strength before the fire.

In bending, for a balanced steel reinforced concrete section the ultimate moment of resistance $\mathrm{M}_{\mathrm{u}}$, is given by [20];

$$
\mathrm{M}_{u}=0.167 \mathrm{f}_{c k} \mathrm{bd}^{2}
$$

After fire the ultimate moment of resistance in flexural compression can be stated as:

$$
\mathrm{M}_{u}^{\prime}=0.167 \mathrm{f}_{c k}^{\prime} \mathrm{b}^{\prime} \mathrm{d}^{\prime 2}
$$

The residual strength index, R.S.I. in flexural compression is given by;

$$
\text { R.S. I. }=\frac{\mathrm{M}_{u}{ }^{\prime}}{\mathrm{M}_{u}}
$$


Flexural tension capacity of the section before fire [20];

$$
\mathrm{M}_{u}=0.87 \mathrm{f}_{y} \mathrm{~A}_{s} \mathrm{Z}
$$

After fire the flexural tension capacity will be:

$$
\mathrm{M}_{u}^{\prime}=0.87 \mathrm{f}_{y}^{\prime \mathrm{A}_{s^{\prime}}} \mathrm{Z}^{\prime}
$$

\section{MATERIALS AND METHOD FOR EXPERIMENTS}

The reinforcement size commonly used in beams and columns in buildings as well as heavy slabs and concrete walls is $\Phi 16 \mathrm{~mm}$. According to BS 4449 [21, 22], $\Phi 16 \mathrm{~mm}$ high yield reinforcement bars should have a nominal diameter of $16 \mathrm{~mm}$, cross-sectional area of $201.1 \mathrm{~mm}^{2}$, specified characteristic strength of $410 \mathrm{~N} / \mathrm{mm}^{2}$ or $460 \mathrm{~N} / \mathrm{mm}^{2}$ as the case may be and with a minimum elongation of 14 . All these properties were determined for each reinforcement specimen. The cement used for the work is Ordinary Portland Cement (OPC). The fine aggregate (sharp sand) and the coarse aggregate $(12 \mathrm{~mm}$ crushed granite) were sourced from local mines and quarries. The water used for the batching of the concrete was portable water acceptable for mixing of concrete.

\subsection{Preparation of Test Specimens}

From full length of the reinforcement, test pieces were cut into specimen lengths of $500 \mathrm{~mm}$ each by a mechanical sawing machine. The form used for the concrete beams were made of timber, with inner length of $550 \mathrm{~mm}$ and having varying depth and width (that is, $56 \mathrm{~mm} \times 56 \mathrm{~mm}, 76 \mathrm{~mm} \times 76 \mathrm{~mm}, 96 \mathrm{~mm} \times 96 \mathrm{~mm}$ and $116 \mathrm{~mm} \times 116 \mathrm{~mm})$. The inner faces of the form work were oiled with petroleum for smooth finish and easy removal of the briquette. The concrete was batched by weight in the ratio 1:2:3 with water cement ratio of 0.5 . After mixing, the concrete and reinforcement specimens were placed alternating in the wood form (concrete half fill, reinforcement and filling to full) with tapping the concrete and vibrating the form with rod and hammer to compact the concrete as for normal constructions. The set briquettes were removed from the form after 24 hours and cured for 28days. Two hours fire exposure is selected as specified in the current code for normal exposure.

i. Samples of reinforcing steel bars of length $500 \mathrm{~mm}$ embedded in various concrete covers $(0 \mathrm{~mm}$, $20 \mathrm{~mm}, 30 \mathrm{~mm}, 40 \mathrm{~mm}, 50 \mathrm{~mm}$,) after curing were exposed to standard fires of temperatures from $200^{\circ} \mathrm{C}$ to $1000^{\circ} \mathrm{C}$ for $2 \mathrm{hrs}$ in a furnace[23].

ii. After cooling to room temperature, the steel bars were removed from the concrete by breaking the concrete cover carefully and tensile test conducted on them.

iii. The reduction factors for the strength of steel at varying temperatures were calculated from the strength proportions before and after fire.

iv. A beam section of width $300 \mathrm{~mm}$, and depth $700 \mathrm{~mm}$ witha concrete cover of $20 \mathrm{~mm}$ was designed and exposed to the fire. The effect of the change in concrete cover to the moment capacity of the beam was then determined.

v. The temperature distribution across the beam section as a result of change in the external temperature due to fire was calculated using the simplified method proposed by Wickström [24] for temperature of concrete due to standard fires as in Equations (6) to (8) below. These equations were used to calculate the strength properties of the beam material using the EC2 [25] formulations.

vi. The strength reduction factor from the experimental work was applied to the beam in order to obtain the residual strength which was then compared with the formulations in the code.

vii. Estimation of the residual strength of steel covered in concrete at various temperatures and cover thicknesses in fire using Equations (9) to (10) were also obtained.

viii. Estimation of the residual strength index (R.S.I.) in flexural tension, flexural compression and flexural shear, of beam using the temperature of the fire, $t$, as in Equations(1) to (5) with both the experimental reduction factor and the theoretical reduction factor.

In the simplified method, according to Wickström [25], the surface temperature of a concrete member exposed to fire is:

$$
T w=N_{w} T_{f}
$$

For a uniaxial heat flow, the temperature, $T_{c}$, at any depth, $x,(m)$ beneath the fire-exposed surface of the member is a factor, $\mathrm{N}_{\mathrm{x}}$, of the surface temperature, $\mathrm{T}_{\mathrm{w}}$, with $\mathrm{N}_{\mathrm{x}}$. This is given by:

$$
T_{c}=N_{x} T_{f}
$$

where, $T_{w}$ is th surface temperature of the member exposed to fire.

$$
N w=1-0.66 t^{-0.88}
$$

$\mathrm{N}_{\mathrm{w}}$ is the ratio between gas and surface temperatures of concrete member $\left({ }^{\circ} \mathrm{C}\right)$, and $\mathrm{T}_{\mathrm{f}}$ is the gas atmosphere temperatures $\left({ }^{\circ} \mathrm{C}\right)$.

$$
N_{x}=0.18 \ln \left(t_{h} / X^{2}\right)-0.81
$$


For corners of beams where there is heat flow from two directions; by superimposition of $\mathrm{N}_{\mathrm{x}}$ and $\mathrm{N}_{\mathrm{y}}$, the temperature is given by:

$$
T c=\left[N_{w}\left(N_{x}+N_{y}-2 N_{x} N_{y}\right)+N_{x} N_{y} T_{f}\right.
$$

The above procedure is used to calculate the temperature attained by the steel reinforcement after two hours of fire duration at $20 \mathrm{~mm}$ thick concrete cover.

Construction steels at normal temperature have a well-defined ultimate yield strength which reduces with increase in temperature according to EC2 [25]. Satish and Santha [27] gave the following equations for the determination of yield strength of reinforcing steel in concrete;

$$
\begin{gathered}
\mathrm{F}_{y}(\mathrm{~T})=\mathrm{F}_{y}\left(20^{\circ} \mathrm{C}\right) \quad \text { for } 0^{\circ} \mathrm{C}<\mathrm{T}<215^{\circ} \mathrm{C} \\
\mathrm{Fy}(\mathrm{T})=\mathrm{Fy}\left(20^{\circ} \mathrm{C}\right) \times\left[\frac{906-T}{690}\right]
\end{gathered}
$$

Here, $\mathrm{T}$ is the temperature of the exposure.

The EC2 [23] expresses that the reduction of the characteristic compressive strength of concrete subjected to a temperature $\mathrm{T}{ }^{\circ} \mathrm{C}$ is given by Equation (11). The range of temperature is indicated in Equations (12) to (15).

$$
f_{c u}(T)=K_{c}(T) \cdot f_{c u}(20)^{\circ} C
$$

For siliceous aggregate

$$
\begin{aligned}
K_{c}(T)= & 1.0 \quad \text { for } 20^{\circ} \mathrm{C}<T \leq 100^{\circ} \mathrm{C} \\
K_{c}(T)= & \left(\frac{1600-T}{1500}\right) ; \text { for } 100<T \leq 400^{\circ} \mathrm{C} \\
K_{c}(T)= & \left(\frac{900-T}{625}\right) ; \text { for } 400<T \leq 900^{\circ} \mathrm{C} \\
& K_{c}(T)=0 ; \text { for } T>900^{\circ} \mathrm{C}
\end{aligned}
$$

\section{RESULTS AND DISCUSSION}

From the tests on reinforcement the following average yield and tensile stresses were obtained as presented in Figures 1 and 2.
From Figures 1 and 2 there is a remarkable change in the yield strength and tensile strength of steel with respect to temperature (from $700^{\circ} \mathrm{C}$ and above) but no remarkable change with respect to concrete cover. It can be seen that when the fire temperature is in the range of $200^{\circ} \mathrm{C}$ to $700^{\circ} \mathrm{C}$, the difference in the strength properties of the heated reinforcing steel from the unheated steel bars is insignificant, while from $800^{\circ} \mathrm{C}$ to $1000^{\circ} \mathrm{C}$ the difference is significant. The reinforcing steel shows a marked strength loss of about $27 \%$ when the temperature is between $800^{\circ} \mathrm{C}$ and $1000^{\circ} \mathrm{C}$. With respect to the variations in concrete cover, it can be seen that there is not much differences in the strength properties of the embedded reinforcing steel bars as the cover increases with respect to the bars without concrete covers at a particular temperature. In order to make these results more explicit the student t-test was applied so as to establish the degree of significance at $95 \%$ confidence level. This test is a valuable tool for comparing means between two populations to determine if there is a significant difference or not. If $\mathrm{t}$-statistic is greater than $\mathrm{t}$-critical at 0.05 level of significance and $p$-value is less than 0.05 then the null hypothesis $\left(\mathrm{H}_{0}\right)$ is rejected and the result are declared statically significant. On the other hand if t-statistic is less than t-critical and p-value is greater than 0.05 then the results are declared statically insignificant and the null hypothesis accepted. The results from the t-test are indicated in Tables 1 to 6 .

Thus, It can be deduced that: the t-statistics at $95 \%$ confidence level from $200^{\circ} \mathrm{C}$ to $700^{\circ} \mathrm{C}$ shows that at

\begin{tabular}{|c|c|c|c|c|c|c|c|c|}
\hline Parameter & 0 cover & $20 \mathrm{~mm}$ cover & 0 cover & $30 \mathrm{~mm}$ cover & 0 cover & $40 \mathrm{~mm}$ cover & 0 cover & $50 \mathrm{~mm}$ cover \\
\hline Mean & 415.03 & 416.24 & 415.03 & 416.24 & 415.03 & 415.59 & 415.03 & 415.64 \\
\hline Variance & 17.77 & 13.23 & 17.77 & 13.23 & 17.77 & 8.83 & 17.77 & 9.55 \\
\hline Observations & 7.0000 & 7 & 7 & 7 & 7 & 7 & 7 & 7 \\
\hline Pearson Correlation & 0.4629 & & 0.4629 & & 0.8556 & & 0.5526 & \\
\hline Hypothesized Mean Difference & 0.0000 & & 0 & & 0 & & 0 & \\
\hline Df & 6.0000 & & 6 & & 6 & & 6 & \\
\hline $\mathrm{t}$-stat & -0.7833 & & -0.7833 & & -0.6499 & & -0.4466 & \\
\hline$P(t \geq T)$ one-tail & 0.2316 & & 0.2316 & & 0.2699 & & 0.3354 & \\
\hline t Critical one-tail & 1.9432 & & 1.9432 & & 1.9432 & & 1.9432 & \\
\hline$P(t \geq T)$ two-tail & 0.4633 & & 0.4633 & & 0.5398 & & 0.6708 & \\
\hline t Critical two-tail & 2.4469 & & 2.4469 & & 2.4469 & & 2.4469 & \\
\hline
\end{tabular}
this range of fire temperature, there is no significant difference in the yield and tensile strength reduction as a result of increases or decreases in the temperature of the reinforcing steel at any particular concrete cover thickness. But from $800^{\circ} \mathrm{C}$ to $1000^{\circ} \mathrm{C}$ there is a significant difference.

Table 1: $t$ - test observation of yield strength between $22^{\circ} \mathrm{C} \& 700^{\circ} \mathrm{C}$ 
Table 2: t-test observation of yield strength between $800 \& 1000^{\circ} \mathrm{C}$

\begin{tabular}{|c|c|c|c|c|c|c|c|c|}
\hline Parameter & 0 cover & $20 \mathrm{~mm}$ cover & 0 cover & $30 \mathrm{~mm}$ cover & 0 cover & $40 \mathrm{~mm}$ cover & 0 cover & $50 \mathrm{~mm}$ cover \\
\hline Mean & 271.83 & 299.58 & 271.83 & 290.24 & 271.83 & 294.48 & 271.83 & 297.60 \\
\hline Variance & 3475.25 & 1016.98 & 3475.25 & 1130.27 & 3475.25 & 927.50 & 3475.25 & 815.65 \\
\hline Observations & 3.0000 & 3 & 3 & 3 & 3 & 3 & 3 & 3 \\
\hline Pearson Correlation & 0.9565 & & 0.900771 & & 0.964629 & & 0.91635 & \\
\hline Hypothesized Mean Difference & 0.0000 & & 0 & & 0 & & 0 & \\
\hline Df & 2.0000 & & 2 & & 2 & & 2 & \\
\hline t-stat & -1.6059 & & -0.9909 & & -1.2804 & & -1.2855 & \\
\hline$P(t \geq T)$ one-tail & 0.1248 & & 0.2131 & & 0.1644 & & 0.1637 & \\
\hline t Critical one-tail & 2.9200 & & 2.9200 & & 2.9200 & & 2.9200 & \\
\hline$P(t \geq T)$ two-tail & 0.2495 & & 0.4262 & & 0.3288 & & 0.3274 & \\
\hline t Critical two-tail & 4.3027 & & 4.3027 & & 4.3027 & & 4.3027 & \\
\hline
\end{tabular}

Table 3: t-test observation of yield strength $b / w 200$ and $1000^{\circ} \mathrm{C}$; effect of temperature

\begin{tabular}{|c|c|c|c|c|c|c|c|c|c|c|}
\hline Temperature $\left({ }^{\circ} \mathrm{C}\right)$ & Mean & 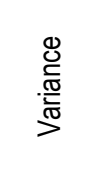 & 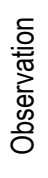 & 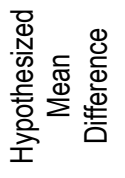 & $d f$ & $\mathrm{t}$-stat & 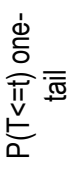 & 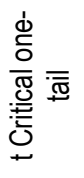 & 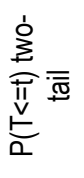 & 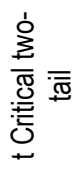 \\
\hline 0 & 414.54 & 0.00 & 5 & 0 & 4 & -7.91 & 0.00 & 2.13 & 0.00 & 2.78 \\
\hline 200 & 418.79 & 1.44 & 5 & & & & & & & \\
\hline 0 & 414.54 & 0.00 & 5 & 0 & 4 & -7.91 & 0.00 & 2.13 & 0.00 & 2.78 \\
\hline 300 & 418.79 & 1.44 & 5 & & & & & & & \\
\hline 0 & 414.54 & 0.00 & 5 & 0 & 4 & 2.42 & 0.04 & 2.13 & 0.07 & 2.78 \\
\hline 400 & 412.16 & 4.83 & 5 & & & & & & & \\
\hline 0 & 414.54 & 0.00 & 5 & 0 & 4 & 0.59 & 0.29 & 2.13 & 0.59 & 2.78 \\
\hline 500 & 413.86 & 6.64 & 5 & & & & & & & \\
\hline 0 & 414.54 & 0.00 & 5 & 0 & 4 & 1.04 & 0.18 & 2.13 & 0.36 & 2.78 \\
\hline 600 & 413.52 & 4.83 & 5 & & & & & & & \\
\hline 0 & 414.54 & 0.00 & 5 & 0 & 4 & 0.19 & 0.43 & 2.13 & 0.86 & 2.78 \\
\hline 700 & 414.31 & 8.22 & 5 & & & & & & & \\
\hline 0 & 414.54 & 0.00 & 5 & 0 & 4 & 48.77 & 0.00 & 2.13 & 0.00 & 2.78 \\
\hline 800 & 332.31 & 14.22 & 5 & & & & & & & \\
\hline 0 & 414.54 & 0.00 & 5 & 0 & 4 & 31.61 & 0.00 & 2.13 & 0.00 & 2.78 \\
\hline 900 & 272.85 & 100.45 & 5 & & & & & & & \\
\hline 0 & 414.54 & 0.00 & 5 & 0 & 4 & 12.64 & 0.00 & 2.13 & 0.00 & 2.78 \\
\hline 1000 & 267.07 & 680.33 & 5 & & & & & & & \\
\hline
\end{tabular}

Table 4): t-test: tensile strength, paired two sample for means between $0 \& 700^{\circ} \mathrm{C}$

\begin{tabular}{|c|c|c|c|c|c|c|c|c|}
\hline Parameter & Omm cover & $20 \mathrm{~mm}$ cover & Omm cover & $30 \mathrm{~mm}$ cover & Omm cover & $40 \mathrm{~mm}$ cover & Omm cover & $50 \mathrm{~mm}$ cover \\
\hline Mean & 641.110 & 641.595 & 641.110 & 644.265 & 641.110 & 644.265 & 641.110 & 643.537 \\
\hline Variance & 18.693 & 16.528 & 18.693 & 23.779 & 18.693 & 25.943 & 18.693 & 19.690 \\
\hline Observations & 7 & 7 & 7 & 7 & 7 & 7 & 7 & 7 \\
\hline Pearson Correlation & 0.647 & & 0.456 & & 0.578 & & 0.672 & \\
\hline Hypothesized Mean Difference & 0.000 & & 0.000 & & 0.000 & & 0.000 & \\
\hline Df & 6.000 & & 6.000 & & 6.000 & & 6.000 & \\
\hline t Stat & -0.364 & & -1.731 & & -1.906 & & -1.808 & \\
\hline $\mathrm{P}(\mathrm{t} \geq \mathrm{T})$ one-tail & 0.364 & & 0.067 & & 0.053 & & 0.060 & \\
\hline t Critical one-tail & 1.943 & & 1.943 & & 1.943 & & 1.943 & \\
\hline$P(t \geq T)$ two-tail & 0.729 & & 0.134 & & 0.105 & & 0.121 & \\
\hline t Critical two-tail & 2.447 & & 2.447 & & 2.447 & & 2.447 & \\
\hline
\end{tabular}


Table 5: t-test: tensile strength-paired two sample for means $b / w 700$ to $1000^{\circ} \mathrm{C}$

\begin{tabular}{|c|c|c|c|c|c|c|c|c|}
\hline Parameter & Omm cover & $20 \mathrm{~mm}$ cover & Omm cover & $30 \mathrm{~mm}$ cover & Omm cover & $40 \mathrm{~mm}$ cover & Omm cover & $500 \mathrm{~mm}$ cover \\
\hline Mean & 506.286 & 538.991 & 506.286 & 537.504 & 506.286 & 535.381 & 506.286 & 544.725 \\
\hline Variance & 11133.402 & 5617.694 & 11133.402 & 6098.704 & 11133.402 & 6177.119 & 11133.402 & 4792.118 \\
\hline $\begin{array}{l}\text { Observations } \\
\text { Pearson Correlation }\end{array}$ & $\begin{array}{l}4 \\
0.971\end{array}$ & 4 & $\begin{array}{l}4 \\
0.949\end{array}$ & 4 & $\begin{array}{l}4 \\
0.944\end{array}$ & 4 & $\begin{array}{l}4 \\
0.919\end{array}$ & 433 \\
\hline Hypothesized Mean Difference & 0.000 & & 0.000 & & 0.000 & & 0.000 & \\
\hline Df & 3.000 & & 3.000 & & 3.000 & & 3.000 & \\
\hline t Stat & -1.757 & & -1.566 & & -1.429 & & -1.535 & \\
\hline$P(t \geq T)$ one-tail & 0.089 & & 0.108 & & 0.124 & & 0.111 & \\
\hline t Critical one-tail & 2.353 & & 2.353 & & 2.353 & & 2.353 & \\
\hline$P(t \geq T)$ two-tail & 0.177 & & 0.215 & & 0.248 & & 0.222 & \\
\hline t Critical two-tail & 3.182 & & 3.182 & & 3.182 & & 3.182 & \\
\hline
\end{tabular}

Table 6: t-test observation of tensile strength $b / w 200$ and $1000^{\circ} \mathrm{C}$

\begin{tabular}{|c|c|c|c|c|c|c|c|c|c|c|}
\hline 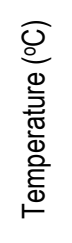 & 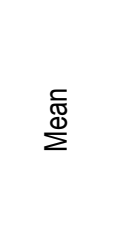 & 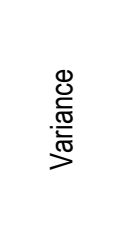 & 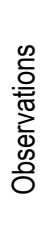 & 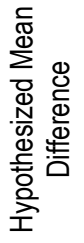 & 告 & 茜 & 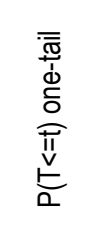 & 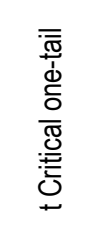 & 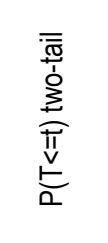 & 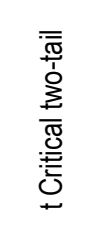 \\
\hline 0 & 635.406 & 0.000 & 5 & 0 & 4 & -5.000 & 0.0037 & 2.1318 & 0.0075 & 2.7764 \\
\hline 200 & 639.653 & 3.608 & 5 & & & & & & & \\
\hline $\begin{array}{c}0 \\
300\end{array}$ & $\begin{array}{l}635.406 \\
647.299\end{array}$ & $\begin{array}{l}0.000 \\
1.082\end{array}$ & $\begin{array}{l}5 \\
5\end{array}$ & 0 & 4 & -25.560 & 0.0000 & 2.1318 & 0.0000 & 2.7764 \\
\hline 0 & 635.406 & 0.000 & 5 & 0 & 4 & -17.963 & 0.0000 & 2.1318 & 0.0001 & 2.7764 \\
\hline 400 & 642.881 & 0.866 & 5 & & & & & & & \\
\hline 0 & 635.406 & 0.000 & 5 & 0 & 4 & -7.990 & 0.0007 & 2.1318 & 0.0013 & 2.7764 \\
\hline 500 & 644.410 & 6.350 & 5 & & & & & & & \\
\hline 0 & 635.406 & 0.000 & 5 & 0 & 4 & -13.371 & 0.0001 & 2.1318 & 0.0002 & 2.7764 \\
\hline 600 & 645.940 & 3.103 & 5 & & & & & & & \\
\hline 0 & 635.406 & 0.000 & 5 & 0 & 4 & -3.967 & 0.0083 & 2.1318 & 0.0166 & 2.7764 \\
\hline 700 & 645.090 & 29.802 & 5 & & & & & & & \\
\hline 0 & 635.406 & 0.000 & 5 & 0 & 4 & 28.792 & 0.0000 & 2.1318 & 0.0000 & 2.7764 \\
\hline 800 & 534.149 & 61.842 & 5 & & & & & & & \\
\hline 0 & 635.406 & 0.000 & 5 & 0 & 4 & 13.887 & 0.0001 & 2.1318 & 0.0002 & 2.7764 \\
\hline 900 & 485.559 & 582.191 & 5 & & & & & & & \\
\hline 0 & 635.406 & 0.000 & 5 & 0 & 4 & 10.190 & 0.0003 & 2.1318 & 0.0005 & 2.7764 \\
\hline 1000 & 465.511 & 1389.811 & 5 & & & & & & & \\
\hline
\end{tabular}

The results obtained for yield stress and tensile stress parameters of the steel reinforcing bars at any fire temperature due to increases in the thickness of the concrete cover indicate that;

The t-statistics at $95 \%$ confidence level from $200^{\circ} \mathrm{C}$ to $700^{\circ} \mathrm{C}$ implies that, there is no significant difference in the yield stress and tensile stress reduction as a result of increases or decreases in the concrete cover to the reinforcing steel at any fire temperature.

There is no significant difference in the strength properties of the reinforcing steel when subjected to various temperatures with respect to the thickness of concrete cover, but there is a significant difference with temperature. The relationship of the yield stresses, tensile stresses and the exposed temperatures for various concrete cover thicknesses is shown in Figures 1 and 2. To make the results more explicit, the proportion of the deteriorated strength to the as-rolled strength tested at ambient temperature was determined and plotted as shown in Figures 3 and 4.

The average strength reduction factors for the reinforced concrete beams after the onslaught of fire from the initial value of the tensile strength were also calculated and shown in Figure 4Construction steels at normal temperatures have a well-defined ultimate yield strength which reduces with increases in temperature as shown Figure 5 according to EC2 [25]. Comparing Figures 4 and 5 , the following can be deduced:

i. From the EC2 [25] specification, the strength starts reducing at $400^{\circ} \mathrm{C}$, whereas from the experiment, the reduction starts at $700^{\circ} \mathrm{C}$ for the steel used. This 
may be due to difference in the crystallization of the steel, laboratory set up, geographical location, etc.

ii. It also shows that applying the code formulations to steel reinforced concrete beams will under estimate the residual strength of the beam in fire. This supports the result obtained by Lenon [8].

The critical temperatures for steel and concrete corresponding to the specific fire temperature according to Wick ström [24] were calculated at the critical points of the beam. The critical point for reinforcing steel is at the lower corner of the beam while the critical point for concrete strength is at the

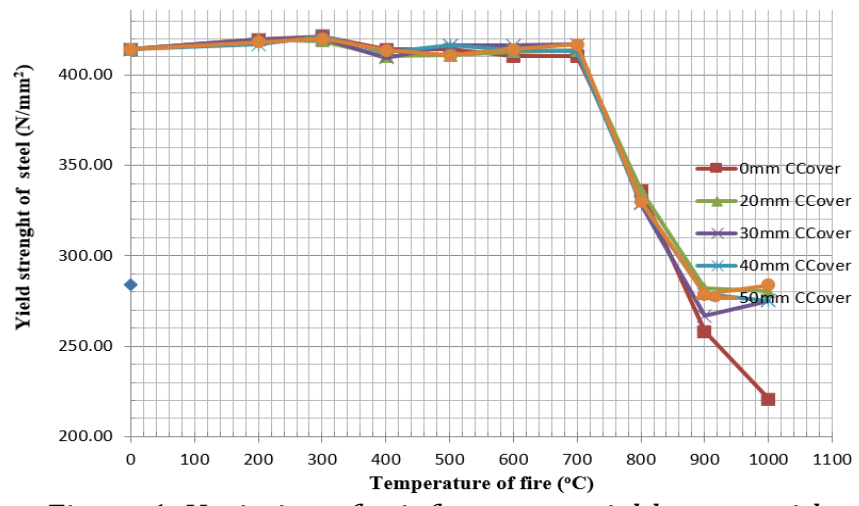

Figure 1: Variation of reinforcement yield stress with temperature and concrete cover

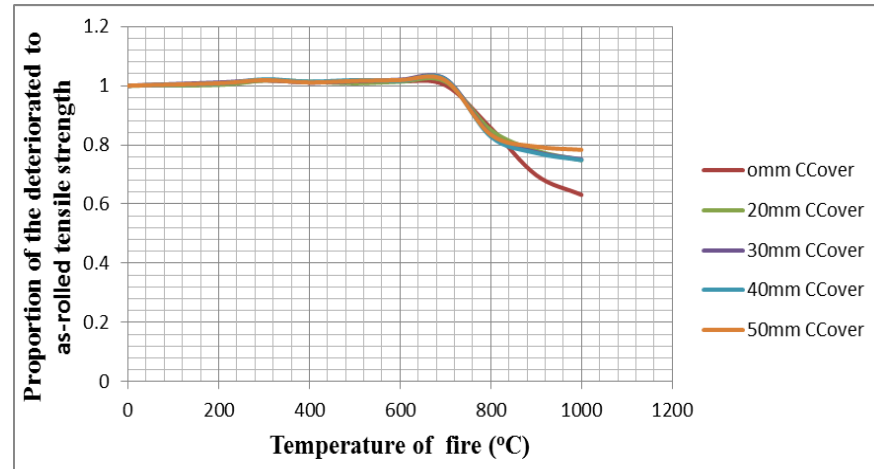

Figure 3: Variation in proportion of tensile strength with temperature

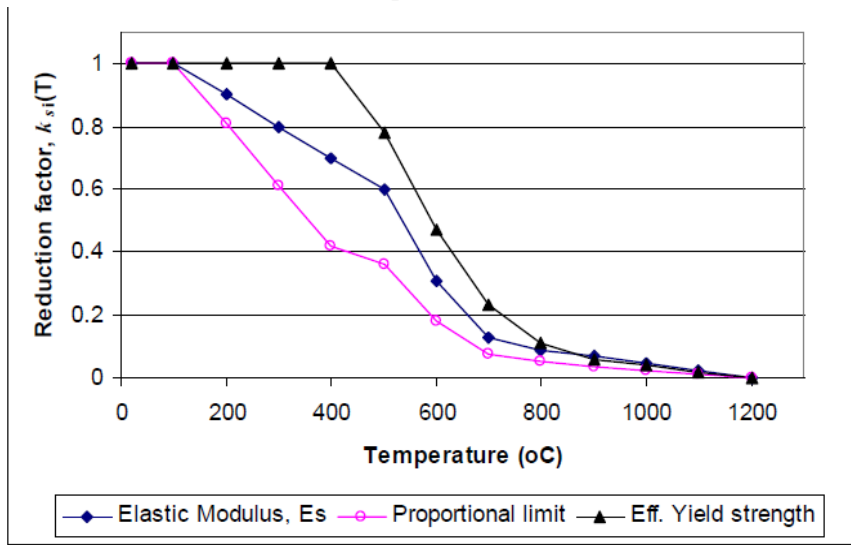

Figure 5: Stress strain relationship of hot rolled reinforcing steels at elevated temperatures [24] neutral axis. The beam section is designed to resist tension at the bottom and compression above the neutral axis. The concrete cover can crack or spall off during fire, and provided the links are not destroyed, the temperature at the thickness of the concrete cover at the top face and up to the neutral axis is taken as the critical temperature of the concrete in compression. The critical temperature of the tensile reinforcement is that at the bottom corner of the beam. The values of these temperatures are not the same for the concrete and steel in the same beam because of their different positions.

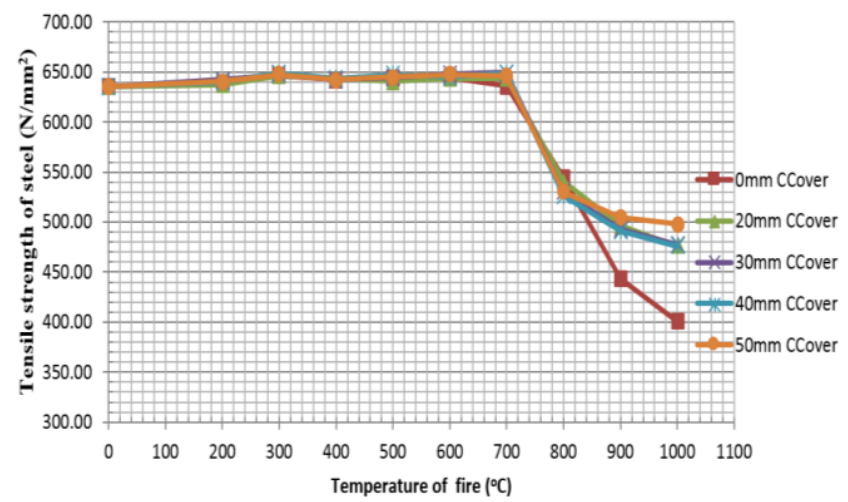

Figure 2: Variation of reinforcement tensile stress with temperature and concrete cover.

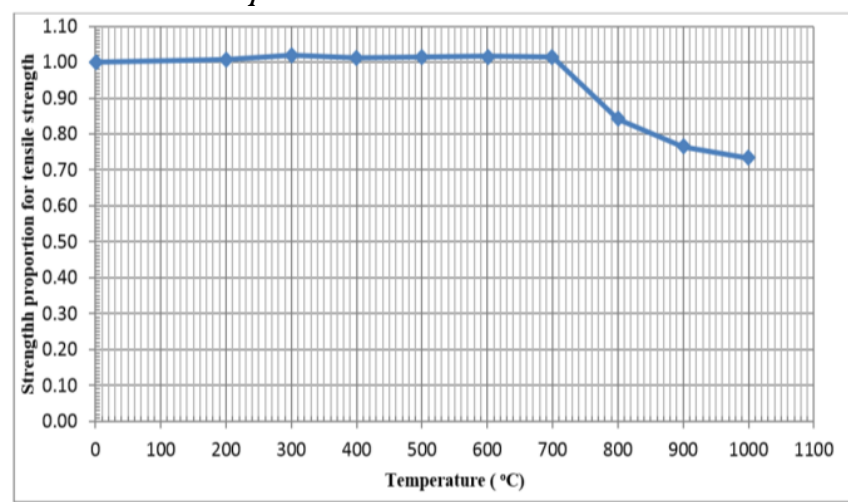

Figure 4: Variation of strength proportion factor of tensile stress with temperature.

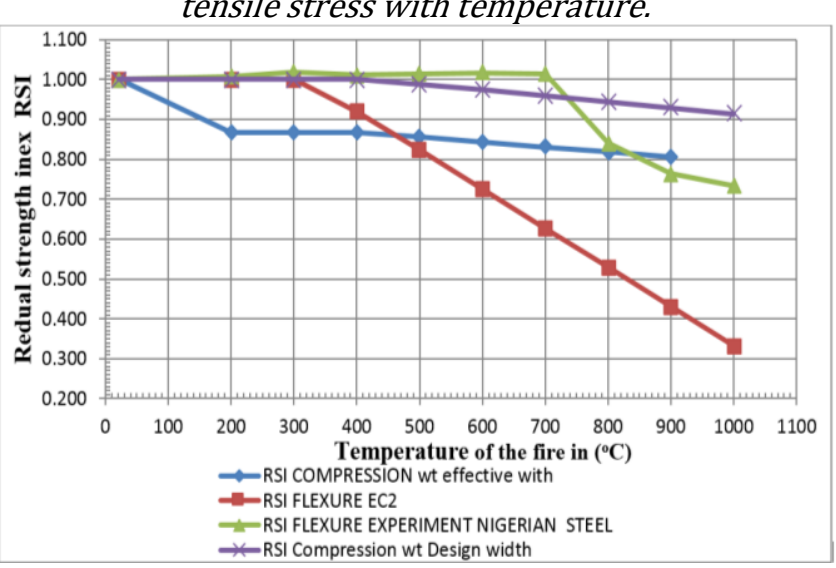

Figure 6: Variation of Residual Strength Index of concrete beams in fire with temperature. 
The moment capacity of the beam in compression, $\mathrm{M}_{\mathrm{u}}$ before fire, after fire, $\mathrm{M}_{\mathrm{u}}{ }^{\prime}$ and the residual strength indices in flexure were calculated at various temperatures using Equations (1) to (5).Similarly, the moment capacity of the beam in flexure, $\mathrm{M}_{\mathrm{u}}$, before fire, after fire $\mathrm{M}_{\mathrm{u}}{ }^{\prime}$ and the residual strength indices were calculated at various temperature using Equations 1 to 5 .

A comparison of the variation in the residual strength indices in fire of the beams in compression and tensile resistance in flexure for the steel used in the experiment and with the formulated in EC2 [25] is shown Figure 6. The following are noted from Figure 6:

i. The residual strength index in compression at varying temperatures will reduce to about $80 \%$ of the initial value at $1000^{\circ} \mathrm{C}$ for the reinforced concrete beam when the temperature of the concrete cover is considered. The assumption here is that because of the stirrups in the beams the concrete may spall or crack at the cover/links interface. The effective width is used to calculate the residual strength.

ii. Assuming the cracked cover is chiselled off and replaced with concrete plaster of almost the same strength as the cover/link interface concrete (interpolated from strength reduction with temperature model), then the reduction in the R.S.I. at $1000^{\circ} \mathrm{C}$ is about $90 \%$ of the original value.

iii. The residual strength index in flexure decreases linearly from $300^{\circ} \mathrm{C}$ as the temperature increases according to the EC2 [25] specification.

Abdu [27] had obtained a similar result with reinforcing steel. The strength of the steel appreciated with temperature to about $750^{\circ} \mathrm{C}$ before decreasing. This may also explain why beams tested by Lenon [8] at National Building Research Centre, London, showed conservative values during the experiments as his results indicated.

\section{CONCLUSION}

The following conclusions can be made from this study:

(i) High temperature has a reduction influence on the ultimate strength of steel. For the steel as indicated in the experiments, the strength appreciates insignificantly from $200-700^{\circ} \mathrm{C}$ before reduction.

(ii) Applying the theoretical model or prediction for direct fire contact with steel according to EC2 [25] the embedded steel in beams during a two hours fire will underestimate the residual strength index of the beam.

(iii) From statistics, it was observed, that the thickness of concrete cover does not affect the reduction in strength properties when subjected to a two hour fire, that is, cover thickness has no significant effect on the strength of the embedded steel reinforcement. This may be attributed to the fact that the thermal conductivity of normal concrete up to a temperature of $400^{\circ} \mathrm{C}$ is very low and insignificantly increases as the temperature increases to about $1000^{\circ} \mathrm{C}$. This corroborates the results of $\mathrm{Hu}$ et al [28] and Hsu and Lin [29].

(iv) From the relationship of residual strength indices of the beam with temperature, the compression resistance at $1000^{\circ} \mathrm{C}$ will reduce to about $80 \%$, if the effective thickness of concrete cover is considered and can be improved to about $90 \%$ by replacing the concrete cover of the affected beam with a new one of approximate strength as cover/link interface concrete.

(iv) For a two hours fire, with maximum temperature not exceeding $700^{\circ} \mathrm{C}$, the flexural capacity due to tensile reinforcement of the beam is still unaffected contrary to the EC2 [25] prediction model.

(v) The compression capacity of the beam is not much affected by the two hours fire exposure. This is because even at $1000^{\circ} \mathrm{C}$ the reduction in concrete compressive strength is just about $10 \%$.

\section{REFERENCES}

[1]. Concrete Center (2010) Concrete and Fire: Using Concrete to Achieve Safe, Efficient Buildings and Structures. www.concretecenter.com/codesstandards/cequal

[2]. Arioglu, E; Koksal, A and Ali, C. (1980) Repair and Strengthening Projects of Aksaray Underground Shopping Center After - Fire. Yapı Merkezi Archives, Çamlıca, Istanbul.

[3]. Bazant, Z. P and Kaplan, M. F. (1996) Concrete at High Temperatures: Material Properties and Mathematical Models. Longman, Harlow.

[4]. Thoft-Christensen, P and Baker, M. J. (1982) Structural Reliability Theory and Its Applications. Springer-Verlag, Berlin. Germany.

[5]. Malhotra, H.L. (1984) Spalling of Concrete In Fires. Technical Note No.118 Construction. 
[6]. Illston, J. M. (1979) Concrete, Timber and Materials. Van Nostrand Reinhold Company, Wokingham, Berkshire, England.

[7]. Institution of Structural Engineers (1975) Fire Resistance of Concrete Structures. Report of a Joint Committee of the Institution of Structural Engineers and the Concrete Society, London.

[8]. Lennon, T. (2004) Fire Safety of Concrete Structures: Background to BS 8110 Fire Design. Building Establishment Bookshop. Watford, London.

[9]. Alonso, C. (2009) Assessment of Post-fire Reinforced Concrete Structures: Determination of Depth of Temperature Penetration and Associated Damage. Concrete Repair, Rehabilitation and Retroitting II Alexander et al (Eds) Taylor \& Francis Group, London, ISBN 978-0-415-46850-3.

[10]. Ellingwood, B. R and Shaver, J. R (1977) Effect of Fire on Reinforced Concrete Members. Journal of the Structural Division. Volume: 82 - 108, pp.1956 1982.

[11] Kodur, V. K. (1999) Fire Performance of High Strength Concrete Structural Members. Construction Technology Update No. 31, National Research Council of Canada, December. pp 1 - 4.

[12]. Dahiru S. (2011) Properties of Concrete Subjected to Various Elevated Temperature. Unpublished Ph.D. Thesis, submitted to the Postgraduate School, Ahmadu Bello University, Zaria. Nigeria.

[13]. Zandi, Yousef; Burnaz, Oguz and Durmuz, Ahmet (2012), Determining the Temperature Distributions of Fire Exposed Reinforced Concrete Cross-Sections with Different Methods. Research Journal of Environmental and Earth Sciences 4(8): 782-788, 2012 ISSN: 2041-0492.

[14].Gerritse, A. (1981) Design Considerations for Reinforced Lightweight Concrete. International Journal of Cement Composites and Lightweight Concrete, Vol. 3, No. 1. pp 57 - 69.

[15].Abeles, P. W and Bardhan-Roy, B. K. (1981) Prestressed Concrete Designer's Handbook.

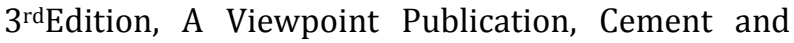
Concrete Association, Wexham Springs, London

[16].Jensen, J.J; Hammer, T.A; Opheim, E; Hansen, P.A.(1995) Fire Resistance of Lightweight Aggregate Concrete. Paper presented at the International Symposium on Structural Lightweight Aggregate Concrete, Sandeford 1995, pp. 192 - 203.
[17].Hammer, T.A.(1995) Spalling Reduction Through Material Design. Report 6.2, HSC Phase 3.SINTEFRapport No. STF70 A95024, Trondheim.

[18]. Danielsen, U; Hammer, T.A; Justnes, H and Smeplass, S. (1988) Marine Concrete Structures Exposed to Hydrocarbon Fires. SINTEF - Report No. STF65 A88064. Trondheim.

[19].Danielsen, U. (1989) Marine Concrete Structures Exposed to Hydrocarbon Fires. Paper presented at a Nordic mini-seminar, SINTEF - Report No. STF65 A89036, Trondheim.

[20].EC2 (2008) Eurocode 2: 2004 ENV 1992 Part 1.The Structural Use of Concrete. European Committee for Standardization, Brussels.

[21].BS 4449 (1969) Specification for Carbon Steel Bars for Reinforcement of Concrete. British Standards Institution, Her Majesty's stationery Office, London.

[22].BS 4449 (1997) Specification for Carbon Steel Bars for Reinforcement of Concrete. British Standards Institution, London.

[23].CCAA (2010) Fire Safety of Concrete Buildings. Cement Concrete and Aggregates, Sydney, Australia.

[24].Wickstrom, U (1987)A Very Simple Method for Estimating Temperature in Fire Exposed Concrete Structures. Swedish National Testing Institute, SP Report, Boras, Sweden.

[25].EC2 (1995) Eurocode 2: Design of Concrete Structures. ENV 1992: Part1 - 2: General Rules Structural Fire Design. European Committee for Standardization, Brussels.

[26].Satish, S. R and Santha, A. R (2010) Design of Steel Structures. Indian Institute of Technology; Madras. Series. Longman Group Limited, U.K.

[27].Abdu, A (1992) Strength Assessment of Steel Reinforcement Subjected to Elevated Temperatures. Unpublished MSc. Thesis, submitted to the Postgraduate School, Ahmadu Bello University, Zaria. Nigeria.

[28].Hu, X. F., T. T. Lie, G. M. Polomark and J. W. Ma Laurin (1993) Thermal Properties of Building Materials at Elevated Temperatures. Institute of Research in Construction, Report No. 643, National Research Council Canada.

[29] Hsu, J. H and Lin, C. S. (2006) Residual Bearing Capabilities of Fire-Exposed Reinforced Concrete Beams. International Journal of Applied Science and Engineering, Vol. 4, No. 2. pp: 151 - 163. 